\title{
Клінічні та морфологічні особливості пухлин зовнішніх статевих органів у жінок, що проходили лікування в Національному інституті раку
}

\author{
Національний інститут раку, Київ \\ Одержано 06.05.2019 \\ Прийнято до друку 12.06.2019 \\ DOI: 10.32471/clinicaloncology.2663-466X.39.22668
}

\begin{abstract}
Об'єкт і методи. У статті наведено результати 3-річного проспективного спостереження у жінок, що звернулися з пухлинами зовнішніх статевих органів (3СО) в Національний інститут раку з 2016 по 2018 р. Результати. Встановлено, що віковими особливостями пацієнток з раком 3 СО є приріст захворюваності після 50 років (17,5\%). Максимальний пік захворюваності встановлено в період 61-70 років $(29,8 \%)$ та у жінок віком старше 71 року $(32,8 \%)(p<0,05)$. За критерієм Т класифікації TNM, найбільшу кількість пацієнток, що звернулися в Національний інститут раку, становили жінки із захворюванням у Т2 клінічній стадії $(53,4 \%)$ порівняно з хворими з Т1 (27,6\%) та Т3 $(10,6 \%)$ клінічними стадіями (р<0,05). 3а критерієм N клінічного стадіювання при зверненні переважали жінки із N0 стадією (70,2\%) проти когорти із N1 (20,6\%) та N2 (4,6\%) стадіями; за критерієм М виявлено більше хворих із М0 стадією $(90,1 \%)$ проти M1 $(6,1 \%)$ та Мх $(3,8 \%)$. За гістопатологічною градацією були верифіковані пухлини високого (G1, 40,5\%), середнього (G2, 38,9\%), низького ступеня диференціювання $(\mathrm{G3}, 19,1 \%)$, а також недиференційовані пухлини (G4, 1,5\%). Згідно зі стадіюванням пухлин 3СО за системою FIGO найбільшу кількість становили хворі з ІІ стадією (39,0\%), практично однаковими були частки пацієнток з I $(20,6 \%)$ та IIIA (18,3\%) стадією раку 3CO; рідше верифікувалися стадії IVA $(12,2 \%)$ та IVB $(6,1 \%)$. При аналізі первинної локалізації пухлини встановлено, що найчастіше діагностувалися новоутворення вульви (64,9\%); пухлини статевих губ становили 25,2\%, пухлини бартолінових залоз - 3,0\%, ураження клітора $-4,6 \%$, задньої статевої спайки $-0,8 \%$, тотальне ураження відмічено у 1,5\% випадків. За гістологічними особливостями більша частина пухлин була представлена плоскоклітинним раком (80,2\%): зроговілим $(59,6 \%)$, незроговілим $(19,1 \%)$ та базальноклітинним $(1,5 \%)$. За допомогою гістологічного дослідження меланому виявлено у 5,3\% хворих, карциному - у 6,9\%, саркому - у 6,1\% пацієнтів; недиференційовані форми раку 3 СО відмічалися рідко та становили 1,5\% звернень. Висновки. За оцінки гінекологічної патології у пацієнтів з пухлинами зСО переважали запальні захворювання сечостатевої системи (29,0\%); серед соматичних захворювань найбільш поширеними у цієї категорії пацієнток були ішемічна хвороба серця (35,9\%) та артеріальна гіпертензія $(25,9 \%)$, рідшими - цукровий діабет $(13,7 \%)$, хронічний бронхіт (10,7\%), виразкові ураження шлунка та дванадцятипалої кишки (13,7\%).
\end{abstract}

Ключові слова: пухлини зовнішніх статевих органів; рак вульви; клінічна характеристика; морфологія.

\section{ВСТУП}

Мета роботи - провести аналіз клінічних та морфологічних особливостей пухлин зовнішніх статевих органів (3СО) у жінок, що проходили лікування в Національному інституті раку з 2016 по 2018 р.

Рак 3 СО становить до 8,0\% загальної захворюваності на злоякісні пухлини жіночих статевих органів і займає четверте місце після раку шийки, тіла матки та яєчників. На сьогодні відмічено приріст цієї патології [1].

Однією із проблем у лікуванні таких пацієнток є пізнє звернення в зв'язку малосимптомним перебігом захворювання в ранній стадії. Як наслідок, до 60,0\% жінок звертаються по медичну допомогу на III-IV стадії захворювання, що є вкрай негативним для прогнозу та ефективного лікування.

У дослідженні Е.А. Јoura та співавтори вивчали статистичні показники, що відображають захворюваність на рак ЗСО в країнах Європейського Союзу. Робота базувалася на ретроспективному аналізі гістологічних даних у жінок, що зверталися з приводу профілактичного огляду або лікування до лікарів первинної ланки. Авторами зазначено, що за останні 10 років захворюваність на рак 3СО у жінок віком до 50 років зросла на $392,0 \%$, інвазивний рак вульви (РВ) - на $157,0 \%$ (p<0,001). Тобто відмічається стійке підвищення цього показника [2].

В інших роботах також підтверджено, що, якщо в минулому столітті ця патологія була характерною для жінок клімактеричного та постклімактеричного віку, то на сьогодні частіше діагностується в більш молодому віці [3, 4]. Доведено, що частим морфологічним «фоном» пухлин цієї локалізації є дистрофічні процеси, які тривалий час відносили до перед- ракових станів. На сьогодні ці ураження вважають доброякісними з ризиком малігнізації 10,0-35,0\% [3, 4].

В Україні, за статистичними даними, стандартизовані показники захворюваності на рак 3СТ становлять 1,3-1,4 випадку на 100000 населення [5], причому приріст захворюваності на рак 3 СО серед молодих жінок пов'язаний з раннім статевим життям, великою кількістю партнерів, невисоким соціально-культурним вихованням, палінням та носійством вірусу папіломи людини [6-9].

Незважаючи на велику кількість досліджень, концепція патогенезу раку 3 СО залишається відкритою навіть дотепер. У літературі можна знайти низку дискусійних питань стосовно причин захворювання, його клінічних особливостей, фонових та передракових станів [10-13]. Зважаючи на географічну варіабельність РВ, не до кінця з'ясовану етіологію, дискусії щодо існуючих методів діагностики та лікування, необхідним $€$ проведення низки додаткових досліджень.

Варто зауважити, що в Україні ми не знайшли подібних досліджень за останні 20 років. Аналізуючи схожі роботи за кордоном, виявили, що, зокрема, в дослідженні Е.В. Коржевської та співавторів вказується, що в 70,0-90,0\% спостережень пацієнтів з пухлинами ЗСО морфологічно верифікується плоскоклітинний рак [16]. Іншими злоякісними пухлинами зазначеної локалізації, за даними цих самих авторів, $є$ меланома, аденокарцинома, саркома та рак бартолінової залози $[15,16]$.

За даними Я.В. Бохмана, частка меланоми вульви, яка відрізняється агресивним клінічним перебігом, серед усіх злоякісних пухлин вульви становить 4,0-6,0\% [17]. V.A. HeinzelmannSchwarz та співавтори зазначають, що кількість випадків злоякісної меланоми сягає від 2,0 до 10,0\% усіх злоякісних 
новоутворень 3СО [18]. Аденокарцинома вульви, за оцінкою Е.Е. Вишневської, виникає в 4,0\% випадків. Рак бартолінової залози становить близько $3,0 \%$ випадків усіх локалізацій раку $3 С$ та представлений аденокарциномою в $60,0 \%$ хворих [19]. На саркому вульви, за даними А.A. Chokoeva та співавторів, припадає $0,2 \%$ усіх новоутворень цієї локалізації [20].

Серед клінічних та вікових особливостей раку 3СО на сучасному етапі, за результатами інших досліджень, ми виявили наступне. У роботі В.А. Пушкарьова та співавторів стосовно аналізу клініко-патологічних особливостей хворих на РВ показано, що на РВ в основному (62,9\%) хворіють жінки віком старше 60 років. Ці самі автори підкреслюють роль профілактичного скринінгового огляду, під час якого можливо виявити $77,3 \%$ хворих із I-II стадією пухлинного процесу [21].

Особливістю локалізації раку ЗСО при ІІІ стадії захворювання, за даними вищезазначеного дослідження, $є$ ураження малих і великих статевих губ $(80,0 \%)$, клітора $(50,0 \%)$; при локалізації в ділянці великих і малих статевих губ, клітора більш ніж у 80,0\% пацієнток виявлено екзофітну форму пухлини; у $38,1 \%$ хворих пухлина була розміром до 2 см в діаметрі, у 22,7\% - більше 4 см [21].

При аналізі супутньої патології встановлено, що екстрагенітальними захворюваннями, за наявності раку 3СО, $є$ серцево-судинні хвороби, патологія органів травлення, ендокринні та метаболічні порушення. Серед гінекологічних факторів ризику виникнення раку відмічено ерозію шийки матки $(69,1 \%)$, метроендометрит $(58,8 \%)$, кольпіт $(71,1 \%)$, лейкоплакію та крауроз вульви $(69,1 \%)$ [21].

\section{ОБ 'ЄКТ І МЕТОДИ ДОСЛІДЖЕННЯ}

Роботу проведено на базі Національного інституту раку. У дослідження включено 131 жінку з раком 3СО. Середній вік становив $62,3 \pm 13,4$ року. Відбір хворих для залучення у дослідження проводився згідно з такими критеріями: 1) вік від 18 до 70 років; 2) письмова згода на участь у дослідженні; 3) морфологічна ідентифікація РВ. Критерії виключення: 1) гострі інфекційні захворювання; 2) наявність пухлин іншої локалізації; 3) наявність клінічно значущої кардіальної патології в анамнезі; 4) наявність ВІЛ-інфекції, вірусних гепатитів В і C; 5) періоди вагітності та лактації; 6) участь у будь-якому іншому дослідженні впродовж останнього місяця.

Перед включенням у дослідження проводилися клінічне обстеження (збір скарг, анамнезу, об’єктивне обстеження), інструментальне обстеження (ультрасонографія, магнітно-резонансна томографія), лабораторні дослідження (загальноклінічне та біохімічне). Верифікацію РВ, стадії захворювання, морфологічної та гістологічної характеристики проводили згідно з рекомендаціями NCCN Clinical Practice Guidelines in Oncology 2017 [14].

Для статистичного аналізу отриманих результатів використовували пакет програм обробки даних загального призначення Statistica for Windows v. 7.0 (Stat Soft inc., США).

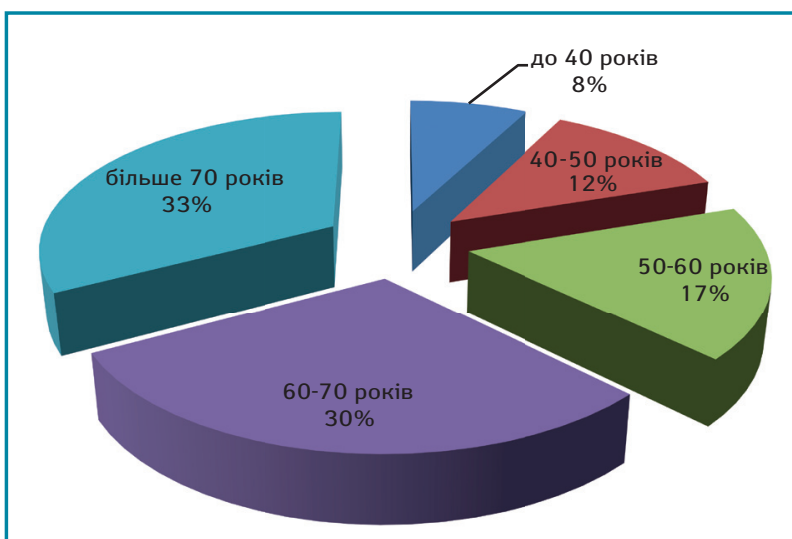

Рисунок. Віковий розподіл пацієнтів з раком ЗСО

\section{РЕЗУЛЬТАТИ ДОСЛІДЖЕННЯ}

За аналізу вікових особливостей пацієнток, що звернулися з приводу раку 3СО, встановлено, що пацієнтки віком до 40 років становили 7,6\% обстежених $(\mathrm{n}=10)$, від 41 до 50 років $-12,2 \%(n=16), 51-60$ років $-17,5 \%(n=23), 61-70$ років $-29,8 \%(n=39), 71$ рік та більше $-32,8 \%(n=43)$. Таким чином, віковими особливостями раку ЗСО серед пацієнток, що звернулися в Національний інститут раку, були хворі віком $60-70$ та $>70$ років.

Розподіл хворих за віковими групами наведено на рисунку.

Класифікації пухлин вульви базуються на кількох принципах, таких як: локалізація пухлини, клінічне або патологічне поширення ураження, тривалість симптомів або ознак, стать та вік хворих, гістологічна будова, ступінь злоякісності [15]. Усі ці ознаки певною мірою впливають на прогноз захворювання, зокрема класифікація TNM. За аналізу співвідношення стадій за TNM класифікацією у пацієнтів, що звернулися з приводу раку 3СО, були отримані дані, що представлені в табл. 1 .

Найбільшу кількість пацієнток за критерієм Т становили жінки із Т2 клінічною стадією - 53,4\% $(\mathrm{n}=70)$, із Т1 клінічною стадією було $27,6 \%(\mathrm{n}=36), \mathrm{T} 3-10,6 \%(\mathrm{n}=14)$. Решта $8,4 \%$ розподілилися між TX $(0,8 \% ; n=1)$, Tis $(2,3 \% ; n=3)$, T1a $(1,5 \% ; n=2), \mathrm{T} 1 \mathrm{~b}(2,3 \% ; n=3)$ та T4 $(1,5 \% ; n=2)$. За критерієм $\mathrm{N}$ клінічного стадіювання пацієнток із N0 стадією було 70,2\% $(\mathrm{n}=92), \mathrm{N} 1-20,6 \%(\mathrm{n}=27)$. Пацієнток із патологічним процесом NX та N2 стадії було по 4,6\% (по n=6) (див. табл. 1).

Таблиця 1. Розподіл хворих з раком ЗСО за клінічною класифікацією TNM

\begin{tabular}{|c|c|c|}
\hline Стадія & $\mathbf{n}$ & $\%$ \\
\hline \multicolumn{3}{|c|}{ Критерій Т } \\
\hline $\mathrm{TX}$ & 1 & 0,8 \\
\hline TO & 0 & - \\
\hline Tis & 3 & 2,3 \\
\hline T1 & 36 & 27,6 \\
\hline T1a & 2 & 1,5 \\
\hline T1b & 3 & 2,3 \\
\hline $\mathrm{T} 2$ & 70 & 53,4 \\
\hline T3 & 14 & 10,6 \\
\hline T4 & 2 & 1,5 \\
\hline \multicolumn{3}{|c|}{ Критерій N } \\
\hline NX & 6 & 4,6 \\
\hline NO & 92 & 70,2 \\
\hline N1 & 27 & 20,6 \\
\hline $\mathrm{N} 2$ & 6 & 4,6 \\
\hline \multicolumn{3}{|c|}{ Критерій М } \\
\hline MX & 5 & 3,8 \\
\hline MO & 118 & 90,1 \\
\hline M1 & 8 & 6,1 \\
\hline \multicolumn{3}{|c|}{ G - гістопатологічна градація } \\
\hline GX & - & - \\
\hline G1 & 53 & 40,5 \\
\hline G2 & 51 & 38,9 \\
\hline G3 & 25 & 19,1 \\
\hline G4 & 2 & 1,5 \\
\hline
\end{tabular}

Таблиця 2. Розподіл хворих проспективної групи за класифікацією FIGO

\begin{tabular}{ccc}
\hline Стадії & $\mathbf{n}$ & $\%$ \\
\hline I & 27 & 20,6 \\
IA & 2 & 1,5 \\
IB & 1 & 0,8 \\
II & 51 & 39,0 \\
IIIA & 24 & 18,3 \\
IIIB & 2 & 1,5 \\
IVA & 16 & 12,2 \\
IVB & 8 & 6,1 \\
\hline
\end{tabular}

Таблиця 3. Розподіл пацієнтів за первинною локалізацією пухлин 3С0

\begin{tabular}{lcc}
\hline \multicolumn{1}{c}{ Локалізація } & $\mathbf{n}$ & \% \\
\hline Вульва & 85 & 64,9 \\
Велика статева губа & 20 & 15,3 \\
Мала статева губа & 9 & 6,9 \\
Ураження обох статевих губ & 4 & 3,0 \\
Задня статева спайка & 1 & 0,8 \\
Бартолінова залоза & 4 & 3,0 \\
Клітор & 6 & 4,6 \\
Тотальне ураження & 2 & 1,5 \\
\hline
\end{tabular}


Таблиця 4. Розподіл хворих на рак ЗСО за морфологічною характеристикою первинної пухлини

\begin{tabular}{lcc}
\hline Морфологічна характеристика первинної пухлини & $\mathbf{n}$ & \% \\
\hline Рак плоскоклітинний, в тому числі: & 105 & 80,2 \\
• рак плоскоклітинний зроговілий & 78 & 59,6 \\
• рак плоскоклітинний незроговілий & 25 & 19,1 \\
• рак базальноклітинний & 2 & 1,5 \\
Меланома, в тому числі: & 7 & 5,3 \\
• меланома веретеноподібна & 1 & 0,8 \\
• меланома злоякісна & 5 & 3,7 \\
• меланома змішана епітеліоїдна & 1 & 0,8 \\
Карцинома, в тому числі: & 9 & 6,9 \\
• аденокарцинома & 5 & 3,7 \\
Саркома, в тому числі: & 8 & 6,1 \\
• саркома веретеноклітинна & 1 & 0,8 \\
• ліпосаркома & 1 & 0,8 \\
- рабдоміосаркома & 1 & 0,8 \\
- ангіолейосаркома & 3 & 2,4 \\
• фібросаркома & 2 & 1,5 \\
Рак недиференційований & 2 & 1,5 \\
\hline
\end{tabular}

За клінічним критерієм М переважали жінки із М0 стадією - 90,1\% (n=118). Пацієнток із М1 стадією було 6,1\% $(\mathrm{n}=8), \mathrm{Mx}-3,8 \%(\mathrm{n}=5)$. За гістопатологічною градацією пухлини високого ступеня диференціювання $(\mathrm{G} 1)$ верифіковані у $53(40,5 \%)$ хворих, середнього (G2) - у $51(38,9 \%)$, низького (G3) - у 25 (19,1\%), недиференційовані пухлини (G4) встановлено у $2(1,5 \%)$ пацієнток (див. табл. 1).

Слід додати, що до класифікації ТNM Міжнародною федерацією гінекологів і акушерів (FIGO) було запропоновано власну систему класифікації та стадіювання. Стадіювання захворювання за FIGO у пацієнток із пухлинами ЗCO наведено в табл. 2. Найбільшу кількість становили пацієнтки із II стадією - 39,0\% (n=51). Практично порівну розподілилися хворі 3 I та IIIA стадіями РB (20,6 та 18,3\%). Стадію IVA верифіковано у $12,2 \%(n=16)$, IVB - у $6,1 \%(n=8)$.

Надалі проводилося вивчення особливостей локалізації первинної пухлини при зверненнях у зв'язку з пухлинами ЗСО (табл. 3). РВ виявлено у найбільшої частки хворих, включених в дослідження, що становило 85 клінічних випадків (64,9\%), пухлини великих статевих губ діагностовано у 20 осіб $(15,3 \%)$, малих статевих губ - у 9 (6,9\%), поєднане ураження у 4 (3,0\%), первинну локалізацію пухлини в бартоліновій залозі відмічено у 4 (3,0\%) пацієнток, ураження клітора - у $6(4,6 \%)$, задньої спайки - у $1(0,8 \%)$ пацієнтки, тотальне ураження у 2 (1,5\%) хворих (див. табл. 3).

Наступним завданням роботи був аналіз морфологічних характеристик первинної пухлини при локалізації в ділянці ЗСО (табл. 4). За гістологічними особливостями більша частина пухлин була представлена плоскоклітинним раком $-80,2 \%$ $(n=105)$, із них зроговілим $-59,6 \%(n=78)$, плоскоклітинним незроговілим $-19,1 \%(\mathrm{n}=25)$ та базальноклітинним $-1,5 \%$ $(\mathrm{n}=2)$ (див. табл. 4). За допомогою гістологічного дослідження меланому ідентифіковано у 7 (5,3\%) хворих, в тому числі веретеноподібну та змішану епітеліоїдну - по 1 випадку $(0,8 \%)$ та злоякісну - у $5(3,7 \%)$ хворих. Карциному виявлено у $9(6,9 \%)$ пацієнтів, із них аденокарциному - у $5(3,7 \%)$ (див. табл. 4).

Саркому верифіковано у $8(6,1 \%)$ пацієнтів: по 1 випадку становили саркома веретеноклітинна $(0,8 \%)$, ліпосаркома $(0,8 \%)$ та рабдоміосаркома $(0,8 \%)$. Ангіолейосаркома виявлена у $3(2,4 \%)$ пацієнтів, фібросаркома - у $2(1,5 \%)$. Ще у $2(1,5 \%)$ хворих діагностували недиференційовані форми раку (табл. 4).

За оцінки супутньої соматичної патології у пацієнтів з пухлинами ЗСО були отримані наведені в табл. 5 дані. 3131 обстеженої жінки вторинні гнійно-запальні процеси органів малого таза відмічалися у $27(20,6 \%)$ випадках. Із супутніх захворювань в анамнезі відзначалися: запальні захворювання сечовидільної системи - у 38 (29,0\%), цукровий діабет в стадії компенсації та субкомпенсації - у 18 (13,7\%), ішемічна хвороба серця у $47(35,9 \%)$, артеріальна гіпертензія - у 34 (25,9\%), хронічний бронхіт - у $14(10,7 \%)$, хронічний гастродуоденіт та пептичні ви- разки шлунка і дванадцятипалої кишки - у $18(13,7 \%)$, хронічний калькульозний холецистит - у 3 (2,3\%), хронічний некалькульозний холецистит - у 12 (9,2\%), хронічний панкреатит - у $8(6,1 \%)$ хворих (див. табл. 5).

Таблиця 5. Супутня патологія при пухлинах 3С0

\begin{tabular}{lcc}
\hline \multicolumn{1}{c}{ Патологія } & $\mathbf{n}$ & \% \\
\hline Запальні процеси органів малого таза & 27 & 20,6 \\
Запальні захворювання сечовидільної системи & 38 & 29,0 \\
Цукровий діабет & 18 & 13,7 \\
Ішемічна хвороба серця & 47 & 35,9 \\
Артеріальна гіпертензія & 34 & 25,9 \\
Хронічний бронхіт & 14 & 10,7 \\
Хронічний гастродуоденіт та/або виразка & 18 & 13,7 \\
Хронічний калькульозний холецистит & 3 & 2,3 \\
Хронічний некалькульозний холецистит & 12 & 9,2 \\
Хронічний панкреатит & 8 & 6,1 \\
\hline
\end{tabular}

\section{ВИСНОВКИ}

За результатами 3-річного проспективного спостереження, проведеного в Національному інституті ракуз 2016 по 2018 р., встановлено низку клініко-морфологічних особливостей пухлин 3 СО.

1. За віковим розподілом пацієнток, що звернулися з приводу пухлин ЗСО в Національний інститут раку, відмічено прогресивний тренд приросту захворюваності, починаючи з 51 року життя $(17,5 \%)$. Максимальний пік захворюваності на рак 3 СО встановлено в період $61-70$ років $(29,8 \%)$ та у жінок старше 71 року $(32,8 \%)(\mathrm{p}<0,05)$.

2. За критерієм T класифікації TNM найбільшу кількість пацієнток, що звернулися в Національний інститут раку, становили жінки із Т2 клінічною стадією $(53,4 \%)$ порівняно 3 хворими з Т1 $(27,6 \%)$ та Т3 $(10,6 \%)$ клінічними стадіями $(\mathrm{p}<0,05)$. За критерієм $\mathrm{N}$ клінічного стадіювання при зверненні переважали жінки із N0 стадією $(70,2 \%)$ проти N1 $(20,6 \%)$ та N2 $(4,6 \%)$; за критерієм М було більше хворих із М0 стадією $(90,1 \%)$ порівняно М1 $(6,1 \%)$ та Мх $(3,8 \%)$ стадіями. За гістопатологічною градацією були верифіковані пухлини високого (G1, 40,5\%), середнього (G2, 38,9\%), низького ступеня диференціювання $(\mathrm{G} 3,19,1 \%)$, а також недиференційовані пухлини $(\mathrm{G} 4,1,5 \%)$.

3. Згідно зі стадіюванням пухлин $3 \mathrm{CO}$ за системою FIGO найбільшу кількість становили хворі з ІІ стадією (39,0\%), практично однаковими були частки пацієнток з I (20,6\%) та IIIA $(18,3 \%)$ стадією раку 3СО; рідше верифікувалися стадії IVA $(12,2 \%)$ та IVB $(6,1 \%)$.

4. У ході аналізу первинної локалізації пухлини виявлено, що найчастіше діагностувалися новоутворення вульви (64,9\%); пухлини статевих губ становили $25,2 \%$, бартолінових залоз $3,0 \%$, ураження клітора $-4,6 \%$, задньої статевої спайки $0,8 \%$, тотальне ураження відмічено у $1,5 \%$ випадків.

5. За гістологічними особливостями більша частина пухлин була представлена плоскоклітинним раком $(80,2 \%)$ : зроговілим $(59,6 \%)$, незроговілим $(19,1 \%)$ та базальноклітинним $(1,5 \%)$. За гістологічним дослідженням меланому виявлено у $5,3 \%$ хворих, карциному - у 6,9\%, саркому - у 6,1\% пацієнтів; недиференційовані форми раку 3 СО відмічалися рідко та становили 1,5\% звернень.

6. При оцінці гінекологічної патології у пацієнтів з пухлинами ЗСО встановлено, що переважали запальні захворювання сечостатевої системи $(29,0 \%)$; серед соматичних захворювань найбільш поширеними у цієї категорії пацієнток були ішемічна хвороба серця $(35,9 \%)$ та артеріальна гіпертензія $(25,9 \%)$, рідшими - цукровий діабет (13,7\%), хронічний бронхіт $(10,7 \%)$, виразкові ураження шлунка та дванадцятипалої кишки $(13,7 \%)$.

\section{СПИСОК ВИКОРИСТАНОÏ ЛІТЕРАТУРИ}

1. Kupets, R., Giede, K. C., Power, P., Agrawal, A. (2016). The investigations require d before referring a patient to a gynaecologic oncologist. Executive of the Society of Gynecologic Oncology of Canada. Journal of Obstetrics and Gynaecology Canada, 38(2), 164-167. DOI: 10.1016/j.jogc.2015.12.016

2. Joura, E. A., Ault, K. A., Bosch F. X., Brown, D., Cuzick, J., Ferris, D. ... Velicer, C. (2014). Attribution of 12 high-risk human papillomavirus genotypes to infection and cervical disease. Cancer Epidemiology, Biomarkers \& Prevention, 23(10), 1997-2008. DOI: $10.1158 / 1055-9965 . \mathrm{EPI}-14-0410$.

3. Desouki, M. M., Chamberlain, B. K. \& Li, Z. (2015). The role of immunohistochemistry in the evaluation of gynecologic pathology part 2: a comparative study 
between two academic institutes. Annals of Diagnostic Pathology, 19(5), 296-300. DOI: 10.1016/j.anndiagpath.2015.06.005.

4. Fuh, K.C. (2012). Current management of vulvar cancer. Hematology, Oncology Clinics of North America, 26, 45. DOI: 10.1016/j.hoc.2011.10.006.

5. Федоренко, 3. П., Михайлович, Ю. Й., Гулак Л. О., Горох, Е.Л., Рижов, А. Ю., Сумкіна, О.В., \& Куценко, Л. Б. (2018). Рак в Україні 2016-2017. Захворюваність, смертність, показники діяльності онкологічної служби. Бюлетень Національного канцер-реєстру України. Київ.

6. Go-Eun, B., Yoon, G., Yong-Jung, S., \& Kim, H.S. (2016). High-grade squamous intraepithelial lesion arising adjacent to vulvar lymphangioma circumscriptum: a tertiary institutional experience. Oncotarget, 7(30), 48120-48129. DOI: 10.18632/oncotarget 10158 .

7. Serrano, B., de Sanjosé, S., Tous, S., Quiros, B., Muñoz, N., Bosch, X., \& Alemany, L. (2015). Human papillomavirus genotype attribution for HPVs $6,11,16,18,31,33,45$ 52 and 58 in female anogenital lesions. European Journal of Cancer, 51(13), 1732-1741. DOI: 10.1016/j.ejca.2015.06.001.

8. Futagami, M., Yokoyama, Y., lino, K., Aoki, M., Shoji, T., Sugiyama, T. ... Mizunuma, H. (2015). Investigation of the clinicopathological features of squamous cell carcinoma of the vulva: a retrospective survey of the Tohoku Gynecologic Cancer Unit. Oncol International Journal of Clinical Oncology, 20(5), 1005-1011. DOI: 10.1007/s10147-015-0803-x.

9. Ramakrishnan, S., Partricia, S., \& Mathan, G. (2015). Over view of high-risk HPV's 16 and 18 infected cervical cancer: pathogenesis to prevention. Biomed Pharmacother, 70, 103-110. DOI: 10.1016/j.biopha.2014.12.041.

10. Parkin, D. M., Whelan, S. L., \& Ferlay, J. (2002). Cancer Incidence in Five Continents. Lyon: International Agency for Research on Cancer.

11. Barlow, E. L., Kang, Y. J., Hacker N. F., \& Canfell, K. (2015). Changing trends in vulvar cancer incidence and mortality rates in australia since 1982. International Journal of Gynecological Cancer, 25(9), 1683-1689. DOI: 10.1097/IGC.0000000000000547.

12. Baiocchi, G., Mantoan, H., de Brot Badiglian-Filho L., Kumagai, L. Y., Faloppa, C. C. \& da Costa, A. A. (2015). How important is the pathological margin distance in vulvar cancer? European Journal of Surgical Oncology 41(12), 1653-1658. DOl: 10.1016/jejso.2015.09.024

13. Khanna, N., Rauh, L. A., Lachiewicz, M. P., \& Horowitz, I. R. (2016). Margins for cervical and vulvar cancer. Journal of Surgical Oncology, 113(3), 304-309. DOI: 10.1002/jso.24108.

14. Koh, W. J., Greer, B. E., Abu-Rustum, N. R., \& Campos, S. M. (2017). Vulvar Cancer, Version 1. 2017, NCCN Clinical Practice Guidelines in Oncology. Journal of the National Comprehensive Cancer Network, 15(1) 92-120. DOI: 10.6004/inccn.2017.0008.

15. Hacker, N. F., \& Barlow, E. L. (2015). Staging for vulvar cancer. Best Practice \& Research: Clinical Obstetrics \& Gynaecology, 29(6), 802-811.

16. Коржевская, Е. В., Козаченко, В. П., \& Паяниди, Ю. Г. (2010). Новые классификации злокачественных опухолей женских половых органов (FIGO и TNM). Опухоли женской репродуктивной системы, 2, 71-77.

17. Бохман, Я. В. (2002). Руководство по онкогинекологии. СПб.: Фолиант.

18. Heinzelmann-Schwarz, V. A., Nixdorf, S., Valadan M., Diczbalis, M., Olivier, J., Otton, G. ...Scurry J. P. (2014). A clinicopathological review of 33 patients with vulvar melanoma identifies c-KIT as a prognostic marker. International Journal of Molecular Medicine, 33(4), 784-794. DOI: 10.3892/ijmm.2014.1659.

19. Вишневская, Е. Е. (2002). Предопухолевые заболевания и злокачественные опухоли женских половых органов. Минск: Вышейш. шк.

20. Chokoeva, A. A., Tchemev, G., Cardoso, J. C., Patterson, J.W., Dechev, I., Valkanov, S., ... Wollina, U. (2015). Vulvar sarcomas: short guideline for histopathological recognition and clinical management. Part 1. International Journal of Immunopathology and Pharmacology, 28, 168-177. DOI: 10.1177/0394632015576029.

21. Пушкарев, В. А., Мазитов, И. М., Хуснутдинов, Ш. М., \& Голо, Е. К. (2014). Анализ клинико-патологических особенностей рака вульвы. Медицинский вестник Башкортостана, 9(3), 50-54.

\section{Клинические и морфологические особенности}

опухолей наружных половых органов у женщин, получавших лечение в Национальном институте рака

\section{А.А. Самохвалова, А.В. Турчак, Ю.Г. Ткачиха}

Национальный институт рака, Киев

Резюме. Объект и методы. В статье приведены результаты 3-летнего проспективного наблюдения у женщин, обратившихся с опухолями наружных половых органов (НПО) в Национальный институт рака с 2016 по 2018 г. Результаты. Установлено, что возрастными особенностями пациенток с раком НПО является прирост заболеваемости после 50 лет (17,5\%). Максимальный пик заболеваемости установлен в период 61-70 лет $(29,8 \%)$ и у женщин в возрасте старше 71 года $(32,8 \%)(\mathrm{p}<0,05)$. По критерию T классификации TNM, наибольшее количество пациенток, обратившихся в Национальный институт рака, составляли женщины с заболеванием в Т2 клинической стадии $(53,4 \%)$ по сравнению с больными с Т1 $(27,6 \%)$ и Т3 (10,6\%) клиническими стадиями $(\mathrm{p}<0,05)$. По критерию $\mathrm{N}$ клинического стадирования при обращении преобладали женщины с N0 стадией (70,2\%) против когорты с N1 (20,6\%) и N2 (4,6\%) стадиями; по критерию М выявлено больше больных с М0 стадией $(90,1 \%)$ по сравнению M1 $(6,1 \%)$ и Мх $(3,8 \%)$. По гистопатологической градации были верифицированы опухоли высокой (G1, 40,5\%), средней (G2, 38,9\%), низкой степени дифференцировки (G3, $19,1 \%)$, а также недифференцированные опухоли (G4, 1,5\%). Согласно стадированию опухолей НПО по системе FIGO наибольшее количество составили больные со II стадией $(39,0 \%)$, практически одинаковыми были доли пациенток с I $(20,6 \%)$ и IIIа (18,3\%) стадией рака НПО; реже верифицировались стадии IVA $(12,2 \%)$ и IVB $(6,1 \%)$. При анализе первичной локализации опухоли установлено, что чаще всего диагностировались новообразования вульвы $(64,9 \%)$; опухоли половых губ составляли $25,2 \%$, опухоли бартолиновых желез - 3,0\%, поражения клито$\mathrm{pa}-4,6 \%$, задней половой спайки $-0,8 \%$, тотальное поражение отмечено в $1,5 \%$ случаев. По гистологическим особенностям большая часть опухолей была представлена плоскоклеточным раком $(80,2 \%)$ : ороговевшим $(59,6 \%)$, неороговевшим $(19,1 \%)$ и базальноклеточным (1,5\%). С помощью гистологического исследования меланому выявлено у $5,3 \%$ больных, карциному у 6,9\%, саркому - у 6,1\% пациентов; недифференцированные формы рака НПО отмечались редко и составляли $1,5 \%$ обращений. Выводы. По оценке гинекологической патологии у пациентов с опухолями НПО преобладали воспалительные заболевания мочеполовой системы (29,0\%); среди соматических заболеваний наиболее распространенными у этой категории пациенток были ишемическая болезнь сердца $(35,9 \%)$ и артериальная гипертензия $(25,9 \%)$, более редкими - сахарный диабет $(13,7 \%)$, хронический бронхит $(10,7 \%)$, язвенные поражения желудка и двенадцатиперстной кишки $(13,7 \%)$.

Ключевые слова: опухоли наружных половых органов; рак вульвы; клиническая характеристика; морфология.

Clinical and morphological characteristics in women with tumors of external genitals treated at National Cancer Institute

O.O. Samokhvalova, O.V. Turchak, J.G. Tkalya

National Cancer Institute, Kyiv

Summary. Materials and methods. The article presents the results of a 3-year prospective study in women with tumors of external genitals, which were observated at National Cancer Institute between 2016-2018. Results. It was established progressive trend in the incidence of externalias tumors after 50 years (17.5\%). The maximum incidence rate was established between $61-70$ years $(29.8 \%)$ and after 70 years $(32.8 \%)(\mathrm{p}<0.05)$. By T-criterion (TNM classification) the largest number were women with T2 clinical stage (53.4\%), compared with T1 $(27.6 \%)$ and T3 $(10.6 \%)$ clinical stages $(\mathrm{p}<0.05)$. According to N-criterion women with N0 stage were majority $-70.2 \%$ vs N1 (20.6\%) and N2 (4.6\%) stages. According to M-criterion the majority of patients had M0 stage $(90.1 \%)$ vs. $6.1 \% \mathrm{M} 1$ and $3.8 \% \mathrm{Mx}$. By histopathological grading G1-differentiation (high) had 40.5\% of patients, G2-differentiation (middle) - 38.9\%, G3-differentiation (low) $-19.1 \%$, and undifferentiated tumors $(\mathrm{G} 4)$ were set in $1.5 \%$ women. According to FIGO-staging the majority of women had stage II $(39.0 \%)$, with an equal distribution of patients I (20.6\%) and IIIA $(18.3 \%)$ stages, the rarest stages were IVA (12.2\%) and IVB (6.1\%). Due to the primary localization, vulval tumors were diagnosed as the most often (64.9\%); the tumors of vulvar lips accounted in $25.2 \%$ cases, tumors of Bartholin's glands $-3.0 \%$, clitoris $-4.6 \%$. According to histological characteristics, most of the tumors were represented by squamous cell carcinoma ( $80.2 \%$ ). Melanoma was revealed in 5.3\% patients, carcinoma in $6.9 \%$, sarcoma - in $6.1 \%$; undifferentiated forms of cancerwere set in $1.5 \%$ women. Conclusion. The concominant diseases in patients with external genital tumors were presented by urogenital inflammatory diseases $(29.0 \%)$, in some patients - by ischemic heart disease (35.9\%) and arterial hypertension (25.9\%), rarely - by diabetes mellitus (13.7\%), chronic bronchitis (10.7\%) and stomach ulcer (13.7\%).

Key words: external genital tumors; vulvar cancer; clinical characteristics; morphology.

Aдреса:

Самохвалова Олена Олександрівна

03022, Київ, вул. Ломоносова, 33/43

Національний інститут раку

E-mail:alenasam85@me.com

Correspondence: Samokhvalova Olena 33/43 Lomonosova Str., Kyiv 03022

National Cancer Institute E-mail:alenasam85@me.com 